\title{
INCLUSIVE AND INNOVATION LEARNING: LOOKING FOR AN EDUCATION FOR DIGITAL CITIZENSHIP
}

\author{
F. Rebelo, A. Guimarães \\ Universidade Portucalense (PORTUGAL)
}

\begin{abstract}
There are many global problems that children and young people face today, such as new technologies, digitalization and climate changes, among others. These issues represent new threats to youth, but they also constitute new learning opportunities and contacts relevant to their well-being and growth as human beings. In this sense, the European Parliament, in its Resolution on the rights of the child on the 30th anniversary of the Convention on the Rights of the Child, came to elect inclusion and innovation as the guiding principles of education and training in a world dominated by digital technologies. This study aimed to identify the rights of minors when are using the Internet, the digital platforms and social networks and in all new spaces for digital communication, whether through computers, tablets, smartphones and game consoles. The method consisted of a theoretical and descriptive approach to relevant international instruments for the protection of the rights of children and young people, such as the European Convention on Human Rights, the Convention on the Rights of the Child, the European Social Charter, the European Parliament Resolution and the Council of Europe Strategy on the Rights of the Child (2016-2021). In addition, a critical analysis was carried out, based on the participation of the young people who were also heard, the achievements obtained and the challenges that arise, as well as the concerns and specific needs of adolescence in this area. The results show that the technological means used at the level of personalized education and partnerships between educational establishments have a high potential to combat the inequalities that exist between youth, bridging the digital divide between students from different socio-economic contexts and regions. The digital world presents opportunities, but it also presents risks, namely, harmful content, sexual exploitation, deprivation of privacy and unprotection of personal data, many resulting from the child's own conduct, such as cyber-bullying and self-exposure. Parents and educators feel the inherent difficulties and concerns without knowing how to proceed, digging the generational gap. There is an urgent need to promote access to quality training - "education for digital citizenship" - to combat radicalization and hate speech and ensure the protection of children's rights, promoting more creative, critical and secure digital communication.
\end{abstract}

Keywords: Inclusion and innovation learning, education for digital citizenship, children's rights protection, hate-speech, cyber-bullying.

\section{INTRODUCTION}

This study focuses on children's rights in the age of globalization. First of all, it is important to find out who the children are for this purpose. In Portugal, in the Law for the Protection of Children and Youth in Danger, Law no. 147/99, of September 1, with the changes introduced by Law no. 23/2017 of May 23 , "the terms child or young refer to the person under 18 or the person under 21 who requests the continuation of the intervention initiated before reaching 18 years of age, and also the person up to 25 years old whenever exists, and only while they last, educational or vocational training processes "[article 5, a)]. There is no distinction between the concepts 'children' and 'young people', but we must take into account the differences with regard to maturity, autonomy and respective needs. The Convention on the Rights of the Child (CRC) also does not differentiate the concepts because, in its article 1, it defines 'child' as a 'person under the age of 18'. With regard to the concept of 'young person', it is often defined in national and international legislation, and for certain purposes, as a person between 13 and 25 years old.

In the document called "National Strategy for the Rights of the Child" (NSRC), which we will address below, the term 'children and young' is used and not just 'children', as it is understood that the differentiation between the target audiences their inclusion, which is positive. Having clarified this point, it is important to start indicating the objective of this work, as well as the question to which it is intended to answer. The main objective is to identify the rights of minors and assess the impact that digital media can have on their lives, today, when globalization is already a reality and the access and use of the Internet is quite widespread, especially in the younger age groups. 
That is, it is intended to determine the cost/benefit of such an exposure or, to put it more rigorously, to specifically determine the dangers to which our children are exposed, if and to what extent, and/or what advantages they can derive from it. And what has been done to eliminate the dangers and what can contribute to increase the positive aspects, if they exist. The target children and young, in this context, are obviously Internet users, those who use digital platforms and social networks and move around in new digital communication spaces, using the multiple means that allow them access, such as computers, tablets, smartphones, among others in the same category or suitable for the same functionalities.

The question to be clarified in this study seems to be pertinent, since it is the European Parliament (EP) itself, which, in its Resolution of 26 November 2019, adopted on the occasion of the 30th anniversary of the United Nations Convention on the Rights of Child (CDC), takes a clear position on bringing children and young people closer to digital networks and platforms. The EP points out negative and positive aspects, considering that a reasonable balance should be sought between both and not adopting a position of rejection on principle, claiming that: "there are many global problems that children and young people face today, such as new technologies, digitalization and climate changes, among others. These issues represent new threats to youth, but they also constitute new learning opportunities and contacts relevant to their well-being and growth as human beings". And, also, European Parliament came to elect inclusion and innovation as the guiding principles of education and training in a world dominated by digital technologies, which is remarkable.

There is yet another reason in favour of the legitimacy and timeliness of the issue in question. At a Conference in Lisbon, which marked the celebration of the 30th anniversary of the Convention on the Rights of the Child and the 40th anniversary of UNICEF in Portugal, the Minister of State and the Presidency, Mariana Vieira da Silva, announced that the "National Strategy for Children's Rights "is under public consultation, inviting the participation of society to this debate, and contributions can be made through the Government's website for public consultations. The public consultation started in late 2019 and ended on January 20, 2020. After the end of the consultation period, UNICEF Portugal together with seven organizations drew up a joint opinion and makes recommendations based on the Final Observations of the United Nations Children's Rights Committee, pointing out the need for a critical review of the NSRC, proceeding to a reflection on the current challenges that affect children.

In this work, the next step it is to describe the methodology and then characterize the connections of children and young people to new technologies, to list the problems, difficulties and risks as well as the opportunities that present themselves to understand the challenges of growing in a digital world. Then it follows a brief passage through the main international instruments, such as conventions and treaties and others, to guarantee the rights of children and the defence of their best interests, directly or indirectly, to assess the sufficiency and effectiveness of laws, policies and practices for protecting children. After that, we will look at the proposals contained in the "National Strategy" instrument. The moment presents itself as propitious to launch the debate around this aim and on the presented and discussed proposals and solutions in that document. Then, a critical analysis will be carried out, based on the participation of the young people who were also heard, their achievements and the challenges that arise, as well as the concerns and specific needs of teenagers in this area. UNICEF also made its voice heard calling on the Government to promote participatory reflection following the public consultation on the National Strategy.

\section{METHODOLOGY}

In order to achieve the objectives outlined above and to analyse the main measures proposed by institutions and global decision makers for the protection and defence of children in the face of the phenomenon of globalization, the method used consists either of an essentially qualitative approach or of a quantitative study, based on the listening to the children themselves and their perceptions as the main agents in handling/confronting with digital technologies. Inquiries were a proposed from the United Nations Committee on the Rights of the Child, by the European Commission and the Council of Europe. Consisted of a detailed assessment of the situation of children and young people in terms of their rights in Portugal. It was carried out, in the fields of social protection, well-being family health, integral health, inclusive and equitable education, access to justice and participation and exercise of citizenship. Also, a theoretical and descriptive search will be made of the most relevant international instruments for the protection of the rights of children and young people. 


\section{RESULTS}

\subsection{The challenges of growing in a digital world}

It is in the digital context, with the use of information technologies (ICT), that many children and young people are currently facing the global problems brought about by the access and use of new technologies. Everything becomes more complicated for children who face phenomena such as the spread of digitalization in all its manifestations, in the social, economic and cultural planes, or the dangers of discovering a "freedom without restraint or guidance" or, still, the movements led by young people and widely disseminated on the Internet in the fight against climate change and the sustainability of the planet, in the last year, who challenge them too soon, perhaps, to have to make conscious and informed choices about the future of the world in which they live. However, these problems, which represent, on the one hand, serious threats to children and young people, on the other hand, also constitute new and stimulating challenges and new learning opportunities relevant to their well-being and growth as human beings.

In the same direction, the European Parliament, in its Resolution on the 30th Anniversary of the Convention on the Rights of the Child, elected inclusion and innovation as the guiding principles of education and training in a world dominated by digital technologies [1]. The International Covenant on Economic, Social and Cultural Rights of the United Nations (UN) enshrines in its Article 13 the right to education as a right that derives from the inherent dignity of the human person [2].

These and other national, European and global legislative instruments have enshrined in their texts measures to protect children's rights in digital communication, pointing out ways to exercise responsible citizenship and testing solutions that include inclusion and innovation in education [3]. As is well known, the protection of children and young people has been at the forefront of the concern of many national and international entities, public and private, practically since the beginning of the 20th century and, with even greater intensity, in this 21 st century. It is therefore not surprising that the large number of institutions that, under various forms and means, have made their voices heard on behalf of the youngest.

At the international level, it is important to highlight, first, the Convention on the Rights of the Child (CRC), adopted by the United Nations General Assembly in 1989, considered the maximum universal exponent of safeguarding the rights of the child, having created a Committee on the Rights of the Child, to monitor compliance by States Parties with compliance with the CRC. In addition to this Convention, many others can be referred to, such as the European Convention on Human Rights (ECHR) [4], The International Labour Organization (ILO), the Union European (EU) (Charter of Fundamental Rights of the European Union, Declaration on Promoting Citizenship and the Common Values of Freedom, Tolerance and Non-Discrimination Through Education, Informal Meeting of European Union Education Ministers Paris, 17 March 2015 [5]; the Council of Europe (Council of Europe Charter on Education for Democratic Citizenship and Human Rights Education. Recommendation CM / Rec (2010) 7, 11 May 2010) [6]; the UNICEF / UN / UNESCO Report "The State of the World's Children 2019" from the United Nations Children's Fund, Universal Declaration of Human Rights, Transforming our world: the 2030 Agenda for Sustainable Development, Global citizenship education: Preparing learners for the challenges of the 21st century) [7] [8].

In 2016, the "Strategy for the Rights of the Child" (2016-2021) was adopted by the Council of Europe, under which the 4 CRC principles are recognized: non-discrimination (article 2); the child's best interest (article 3), the child's right to life, survival and development (article 6) and respect for the child's views (article 12). In addition, the document came to establish 5 priorities, among them: equal opportunities; participation; violence-free life; child-friendly justice and the defence of the rights of children and young people in the digital environment. In the economics of this work, it is important to underline the last priority, which must be understood as having the objective of enabling children and young people to use information and communication technologies (ICT) in order to ensure access to information, participation in the digital world, freedom of expression and that, at the same time, can do so with freedom and security.

At the national level, in the field of Education for Citizenship and Sustainable Development, Portugal has been aligned with the key international documents mentioned above, which provide the legal framework and justify many of the commitments assumed in the domestic order.

Firstly, it should be noted that education for citizenship is enshrined in the Basic Law of the Educational System (Law No. 46/86, of 14 October). This diploma establishes the general framework 
of the Portuguese educational system, understood as "the set of means by which the right to education is realized, which is expressed by the guarantee of a permanent formative action oriented to favour the global development of personality, social progress and the democratization of society". This legal diploma expressively establishes [Article 3, b)] the organizational principle that aims to "contribute to the realization of the student, through the full development of personality, character formation and citizenship" of young people [9].

Decree-Law no. 55/2018, of 6 July, in turn, establishes the curriculum for basic and secondary education and the guiding principles for the assessment of learning, recognizing that "society currently faces new challenges, arising from accelerating globalization and technological development, the school having to prepare students, who will be young and adults in 2030 , for jobs not yet created, for technologies not yet invented, for solving problems that are still unknown" (Preamble). In this sense, it was approved by Order no. 6478/2017, of July 26, the document "Profile of Students Leaving Mandatory Schooling" [article 3, 1, i)], which establishes the matrix of principles, values and areas and skills that curriculum development must obey", seeking to respond" to the social and economic challenges of the current world, aligned with the development of 21st century competences"[10]. Right away, the need for "an inclusive school (...) for the exercise of active and informed citizenship throughout life" is proclaimed, which implies that "schools are given autonomy" to design the curriculum that meets the context and to the needs of its students (Preamble to Decree-Law No. $55 / 2018)$.

The United Nations Committee on the Rights of the Child, the European Commission and the Council of Europe encouraged Portugal to develop a comprehensive National Strategy for the implementation of the Convention on the Rights of the Child, including specific objectives and targets to effectively monitor progress in the application of rights of children and young people across the territory.

The National Strategy for the Rights of the Child, for the period 2019-2022 - NSRC, intends to define objectives and implement a coordinated set of intersectoral actions that, starting from the current situation of children and young people in view of the rights stipulated in the Convention, allow, in the horizon of 4 years, guarantee significant progress in the application of their rights and in the participation and exercise of citizenship.

In addition to this assessment, it was considered essential to adopt a participatory methodology involving, in particular, children and young people, who are at the centre of the National Strategy for the Rights of the Child, and members of Commissions for the Protection of Children and Youngs, who will be at the forefront of its implementation.

Within the scope of the "National Strategy for Education for Citizenship", which aims at "the development of skills for a culture of democracy and learning (...), through the Citizenship and Development component [ article 3,1, g)], it is up to each school to approve its citizenship education strategy in the terms set out in article 15. Among the guiding principles, it is worth mentioning $r$ ), paragraph 1 , of article 4 , which provides for the "promotion of education for citizenship and interpersonal personal development and social intervention throughout the entire schooling period. mandatory. Taken as a whole, the aforementioned provisions aim to contribute to the construction of the individual's identity and the development of students' civic awareness [11]. On the page of the Ministry of Education, called "Education for Citizenship", it can be read that: "The Strategy proposes that students in the curricular component of Citizenship and Development carry out learning through the plural and responsible participation of all and everyone in building themselves and a society fairer and becoming more inclusive citizens, within the framework of democracy, respect for diversity and the defence of human rights".

\subsection{Self-assessment by children}

What do the children tell us? Taking into account the fundamental importance of knowing the perception of children and young people regarding the application of the CRC, in November 2015, the Directorate-General for Education conducted a survey and promoted a debate with a representative group of children and young students, of different ages, respecting the balance of gender equality. This group, called "A Voz dos Alunos", reflected on some selected articles from the CRC, and the survey was applied using the anonymous debate and voting methodology. In addition to this assessment, it was considered essential to adopt a participatory methodology involving, in particular, children and young people, who are at the center of the National Strategy for the Rights of the Child (NSRC), and members of Commission for the Protection of Children and Youngs, who will be at the forefront of its implementation. 
The Commissions for the Protection of Children and Youngs across the country were also invited to participate in the preparation of National Strategy for the Rights of the Child (NSRC 2019-2022. Following the participatory methodology, the 82 Commission for the Protection of Children and Youngs, from all over the country, who responded to the challenge, met in their extended form and answered the two questions: "what do we do well" and "what can we improve", regarding the five priorities of NSRC answers received from both students and Commission for the Protection of Children and Youngs.

\subsection{Results discussion}

What answers do the laws give us? What rights have children safeguarded in relation to digitization?

The National Strategy for the Rights of the Child (2019-2022) - NSRC give us answer through the objectives 5, 11 and 14 .

The objective 5 (articles $28,29 \mathrm{CRC}$ ) is dedicated "to guaranteeing access to an inclusive and quality education for all children and young people, contributing to their development physical, cognitive, social and emotional. In this sense, the intention is to reinforce programs to develop inclusive education; by reducing the retention and dropout rate in general basic education and by reducing the rate of students with negative levels, contributing to a flexible and diversified curricular offer in order to guarantee the multiplicity of training paths and promote their integral and welfare". The objective 11 foreseen in articles 2, 8, 13, 14, 29, 42 from CRC intends to increase the participation and exercise of citizenship by minors.

From the objective 14, foreseen in articles 34 and 40 from CRC, it is possible to adapt national legislation regarding children and young people to the CRC. This objective covers the promotion of analysis and study on the adequacy of criminal legislation (article 160 of the Penal Code)[12]; promoting a systemic analysis of the articles of the Penal Code relating to crimes against sexual selfdetermination, with the aim of protecting minors in the circle of trust; assessment of the compliance of the regime provided for in articles 173 and 178, no.3 of the Penal Code, in the context of sexual acts with teenagers, with the provisions of the Lanzarote Convention - Protection of Children against Sexual Exploitation and Sexual Abuses.

The Council of Europe also gives us some important reflections in its priority area 5 about children's rights in the digital environment.

\subsection{Structural Measures of NSRC}

Firstly, the Member States and other target groups change legislation and policies to protect children in the digital environment [13].

Por example, increasing levels of security in access to digital media by children and young people. The "SeguraNet" project has the mission of promoting safe, critical and informed navigation of the internet and mobile devices by the educational community (students, teachers and guardians) [14].

Very important it is to create a guidance on an integrated approach to children's rights in the digital environment and promote the participation and access of children and young people to citizenship rights [15]. Taking into account the recent publication of Decree-Law No. 55/2018, of 6 July, and the provisions of the Regional Legislative Decree no. 21/2010 / A, of 24 June, and in Regional Regulatory Decree no. 17/2011 / A, of 2 August, the curriculum guidelines contained in the National Strategy for Education for Citizenship, a component of Citizenship and Development (Article 15).

Another measure to achieve monitoring of cybercrime, data protection and security conventions sexual exploitation and sexual abuse it is the creation of the Observatory for the Rights of the Child [16].

Establishment of a global data collection and analysis system related to the application of children's rights provided for in the CRC.

To promote intercultural education, we need Citizenship and Development curricular unit itself as a privileged curricular space for the development of learning [17]. A recent news: Amnesty International Portugal will launch a collection of manuals and a website that reinforces its content offer in the area of Education for Citizenship [18].

And finally, strengthening inclusive education promotion programs, namely promote 'no to hate speech' campaigns and also through the Pan-European Project on education for digital citizenship. 


\section{CONCLUSIONS}

The technological means used at the level of personalized education and partnerships between educational establishments have a high potential to combat the inequalities that exist between youth, bridging the digital cleavage between students from different socio-economic contexts and regions.

The digital world presents opportunities, but it also presents risks, namely, harmful content, sexual exploitation, deprivation of privacy and unprotection of personal data, many resulting from the child's own conduct, such as cyber-bullying and self-exposure.

The defence of the rights of children and young people in the digital environment, aims to empower children and young people to make use of the potential of Information and Communication Technologies (ICT), guaranteeing their access to information, freedom of expression and participation in the digital world, in while protecting against potential risks associated with the use of such technologies

Parents and educators feel the inherent difficulties and concerns without knowing how to proceed, digging the generational gap.

There is an urgent need to promote access to quality training - "education for digital citizenship" - to combat radicalization and hate speech and ensure the protection of children's rights, promoting more creative, critical and secure digital communication.

\section{REFERENCES}

[1] Considerando H da Resolução do Parlamento Europeu, de 26 de novembro de 2019, sobre os Direitos da Criança por ocasião do $30 .^{\circ}$ aniversário da Convenção das Nações Unidas sobre os Direitos da Criança (2019/2876(RSP)].

[2] M. Pando Ballesteros, P. Garrido Rodríguez and A. Muñoz Ramírez, El cincuentenario de los Pactos Internacionales de Derechos Humanos de la ONU: Homenaje a la Profesora M ${ }^{a}$. Esther Martínez Quinteiro. Salamanca: Ediciones Universidad de Salamanca, 2018.

[3] F. Rebelo, "The protection of minors in the digital age". In I. Blanco Alfonso, L. M. FernándezMartínez, \& R. Suárez-Álvarez (Eds.), Vulnerabilidad y cultura digital: riesgos y oportunidades de la sociedad hiperconectada (Cap. III, pp. 269-285). Madrid: Editorial Dykinson, 2019. Retrieved from: http://hdl.handle.net/11328/3132.

[4] A. Guimarães and F. Rebelo, "Fundamentos da privação da liberdade II". In P. P. Albuquerque (Org.), Comentário da Convenção Europeia dos Direitos Humanos e dos protocolos adicionais (vol. 1, pp. 815-853). Lisboa: Universidade Católica Editora, 2019. Retrieved from: http://hdl.handle.net/11328/2989; J. Merrills, A. Robertson, Direitos Humanos na Europa. Um estudo da Convenção Europeia dos Direitos Humanos. Bobadela: Instituto Piaget, 2005,

[5] Declaration on Promoting Citizenship and the Common Values of Freedom, Tolerance and NonDiscrimination through Education. Informal Meeting of European Union Education Ministers Paris, 17 March 2015. http://ec.europa.eu/education/news/2015/ documents/citizenship-educationdeclaration_en.pdf.

[6] Council of Europe Charter on Education for Democratic Citizenship and Human Rights Education. Recommendation CM/Rec(2010)7, 11 may 2010. https://rm.coe.int/CoERMPublicCommon SearchServices/DisplayDCTMContent?documentld=09000016803034e3.

[7] Organização das Nações Unidas (2015). Transforming our world: the 2030 Agenda for Sustainable Development. Resolução A/RES/70/1, Assembleia Geral das Nações Unidas, 25 de setembro de 2015.http://www.un.org/ga/search/view_doc.asp?symbol=A/RES/70/1\&Lang=E

[8] UNESCO (2014). Global citizenship education: Preparing learners for the challenges of the 21st century. Paris: Autor. http://unesdoc.unesco.org/images/0022/002277/227729E.pdf.

[9] L. Capucho, Educação para a Cidadania. Guião de Educação do Consumidor. Lisboa: Ministério da Educação, Direção-Geral de Inovação e de Desenvolvimento Curricular, 2006.

[10] AAVV (Despacho n. ${ }^{\circ}$ 6478/2017, 26 de julho), O Perfil dos Alunos à Saída da Escolaridade Obrigatória. Lisboa: Ministério da Educação/Direção-Geral da Educação, 2017. 
[11] Grupo de trabalho de Educação para a Cidadania (GTEC) criado por Despacho conjunto, no. 6173/2016, de 10 de maio de 2016, da Secretária de Estado para a Cidadania e a Igualdade e do Secretário de Estado da Educação, Estratégia Nacional de Educação para a Cidadania. Lisboa: República Portuguesa. XXI Governo Constitucional, 2017.

[12] A. Guimarães and F. Rebelo, "Education for human rights, it's needed", INTED2019 Proceedings (pp. 6950-6956), 2019. Retrieved from: doi: 10.21125/inted.2019.1683. http://hdl.handle.net/ $11328 / 2652$.

[13] B. Borges, "Promoção e protecção de crianças e jovens em perigo: perspectivas futuras do modelo judicial", Julgar, 24, 167-186, 2014. Retrieved from: http://julgar.pt/wpcontent/uploads/2014/09/11-Beatriz-M-Borges-Promo\%C3\%A7\%C3\%A3o-eprotec\%C3\%A7\%C3\%A3o-perspectivas-de-futuro.pdf.

[14] G. Van Bueren, Child Rights in Europe. Convergence and divergence in judicial protection (2234). Conselho da Europa: Council of Europe Publishing, 2007.

[15] CM / Rec (2014) 6 for a Guide on Human Rights for Internet users.

[16] CM / Rec (2009) 5 on measures to protect children from harmful content and behaviour and to promote their active participation in the new information and communication environment.CM / $\operatorname{Rec}$ (2009) 5 on measures to protect children from harmful content and behaviour and to promote their active participation in the new information and communication environment.

[17] Council of Europe Strategy for the Rights of the Child (2016-2021). Human rights of child. Documents and Publications Production Department (SPDP).

[18] Amnesty International Portugal. https://www.amnistia.pt/amnistia-alarga-projeto-das-escolasamigas-dos-direitos-humanos/l. 